\title{
Peramalan Produksi Kelapa Sawit (Elaeis guineensis Jacq.) di Perkebunan Sei Air Hitam berdasarkan Kajian Faktor Agroekologi
}

\author{
Production Estimation of Oil Palm (Elaeis guineensis Jacq.) in Sei Air Hitam Estate Base on \\ Agroecological Factors
}

\author{
Munandar Irfanda ${ }^{1}$, Edi Santosa ${ }^{*}$ \\ ${ }^{1}$ Departemen Agronomi dan Hortikultura, Fakultas Pertanian, Institut Pertanian Bogor \\ (Bogor Agricultural University), Jl. Meranti, Kampus IPB Darmaga, Bogor 16680, Indonesia \\ Telp. \& Faks. 62-251-8629353 e-mail agronipb@indo.net.id \\ *Penulis untuk korespondensi: edisang@gmail.com
}

Disetujui 14 November 2016 / Published online 8 Desember 2016

\begin{abstract}
The internship was conducted at Sei Air Hitam Estate, Rokan Hulu, Riau, from February to May 2012. The objective of this assignment was to determine agronomic and agroecological characters responsible to estimate oil palm production. The assignment composed of several works, i.e., as field worker for three weeks, as assistant foreman for three weeks, and as estate assistant companion for six weeks. Specific topic studied was evaluation of the agronomic and agroecological characters which were affected oil palm production. Result of t-parcial test indicated that there were seven variables affected oil palm production at $\alpha=1 \%$ and $\alpha=5 \%$ i.e., plant ages, fertilizer application, air humidity, wind speed, number of rainy day, rainfall, and water deficit. Result of multiple regression analysis showed that there were six model comparison which able to be used to estimate oil palm production in Sumatera.
\end{abstract}

Keyword : agroecological parameters, oil palm production, production estimation, Sumatera

ABSTRAK

Kegiatan magang dilakukan di Sei Air Hitam Estate, Rokan Hulu, Riau, pada Februari sampai Mei 2012. Tujuan dari kegiatan ini adalah untuk menentukan hubungan karakter agronomi dan agroekologi dengan peramalan produksi kelapa sawit. Kegiatan magang terdiri dari beberapa pekerjaan yaitu sebagai karyawan harian lepas selama tiga minggu, sebagai pendamping mandor selama tiga minggu, dan sebagai pendamping asisten selama enam minggu. Pengamatan khusus dilakukan sebagai kegiatan tambahan misalnya mengevaluasi karakter agronomi dan agroekologi yang mempengaruhi produksi kelapa sawit. Hasil dari uji t-parsial mengindikasikan bahwa terdapat tujuh variabel yang mempengaruhi produksi kelapa sawit pada $\alpha=1 \%$ dan $\alpha=5 \%$ yaitu umur tanaman, aplikasi pemupukan, kelembaban udara, kecepatan angin, hari hujan, curah hujan, dan defisit air. Hasil analisis regresi menunjukkan bahwa terdapat enam model persamaan yang dapat digunakan untuk meramalkan produksi kelapa sawit di Sumatera.

Kata kunci : parameter agroekologi, peramalan produksi, produksi kelapa sawit, Sumatera 


\section{PENDAHULUAN}

Kelapa Sawit (Elaeis guineensis Jaqc.) merupakan tanaman komoditas perkebunan yang cukup penting di Indonesia dan masih memiliki prospek pengembangan yang cukup cerah. Permintaan dunia akan minyak sawit setiap tahun meningkat rata-rata $6.5 \%$ pertahun.

Menurut Setyamidjaja (2006) kelapa sawit dapat menghasilkan beberapa jenis produk industri yaitu: minyak sawit (CPO), minyak inti sawit (PKO), minyak goreng, minyak salad, sabun, gliserin, margarine dan sekian banyak lagi produk turunannya termasuk minyak bakar kendaraan bermotor yang saat ini masih belum merupakan produk utama kelapa sawit.

Menurut Sunarko (2009) perkembangan luas dan produksi perkebunan kelapa sawit di Indonesia selama sepuluh tahun terakhir telah meningkat dari 2.2 juta ha pada tahun 1997 manjadi 4.1 juta ha pada tahun 2007 atau meningkat $7.5 \%$ pertahun. Menurut data BPS (2010) produksi minyak kelapa sawit meningkat dari 11437986 ton pada tahun 2007 menjadi 14 290054 ton pada tahun 2010 dengan luasan 5 juta ha.

Faktor agroekologi yang spesifik seperti iklim, tanah, suhu, cahaya matahari, dan angin sangat mempengaruhi produksi kelapa sawit. Menurut Sastrosayono (2003) curah hujan yang baik untuk pertumbuhan dan produksi tanaman kelapa sawit adalah diatas $2000 \mathrm{~mm}$ dan merata sepanjang tahun. Menurut Setyamidjaja (2006) lama penyinaran yang dibutuhkan oleh kelapa sawit adalah 5-7 jam/hari. Lama penyinaran terutama berpengaruh terhadap pertumbuhan dan tingkat asimilasi, pembentukan bunga (sex ratio), dan produksi buah. Menurut Pahan (2010) tanaman kelapa sawit dapat tumbuh dengan baik pada kisaran suhu $24-28{ }^{\circ} \mathrm{C}$. Penyerbukan kelapa sawit (anemophyli) efektif pada kecepatan angin 5-6 km/jam. Menurut Setyamidjaja (2006) kelapa sawit menghendaki kelembaban udara sekitar $80 \%$.

Menurut Aritonang (2009) peramalan produksi merupakan bagian penting bagi setiap perusahaan perkebunan kelapa sawit. Peramalan memberikan dasar dalam proyeksi pendapatan, penentuan anggaran dan pengendalian biaya. Data peramalan menjadi masukan penting pada perencanaan kapasitas produksi, sarana produksi, dan penjadwalan. Namun, seringkali masalah agroekologi seperti iklim, tanah, dan sinar matahari mempengaruhi akurasi hasil peramalan produksi kelapa sawit sehingga akurasi peramalan kurang dan berdampak pada merugikan perusahaan.

\section{BAHAN DAN METODE}

Kegiatan magang dilaksanakan pada bulan Februari sampai Mei 2012, bertempat di perkebunan Sei Air Hitam Estate (SAHE), Kabupaten Rokan Hulu, Riau. Di lokasi magang tidak terdapat kegiatan pembibitan dan tanam, sehingga magang difokuskan pada kegiatan pemeliharaan dan panen.

Selama tiga minggu pertama, penulis berstatus sebagai buruh harian lepas (BHL). Kemudian tiga minggu kedua berstatus sebagai pendamping mandor dan enam minggu terakhir terakhir berstatus sebagai pendamping asisten divisi. Pengumpulan data primer dilakukan dengan diskusi dan wawancara dengan karyawan, mandor dan staf kebun serta melakukan pengamatan secara langsung di lapangan. Pengumpulan data sekunder dilakukan dengan mengutip data yang dimiliki perusahaan dan Badan Meteorologi, Klimatologi, dan Geofisika (BMKG).

Data agroekologi dianalisis menggunakan persamaan yang dikembangkan oleh Sulistyo (2010). Jika hasil ramalan tidak ada yang mendekati aktual (akurasi kurang dari 85\%) maka akan dikembangkan persamaan yang baru.

Analisis data yang dilakukan adalah dengan melakukan uji t-parsial dan Regresi Linear Berganda (RLB) menggunakan program aplikasi Minitab 14 untuk mengetahui parameter agronomi yang berpengaruh terhadap produksi tandan buah segar kelapa sawit.

\section{HASIL DAN PEMBAHASAN}

\section{Kondisi Umum}

Curah hujan rata-rata tahunan di lokangsi maga dalam kurun waktu 7 tahun terakhir (20052011) adalah 2,345.14 mm/tahun dengan jumlah hari hujan pertahun rata-rata 107 hari. Menurut kelas iklim Schmidth-Ferguson, keadaan iklim setempat termasuk dalam tipe iklim A, yaitu daerah sangat basah dengan curah hujan rata-rata $2345.14 \mathrm{~mm} /$ tahun (rata-rata 7 tahun terakhir).

Areal magang memiliki kondisi topografi dengan kemiringan 1-3\% seluas 2476 ha. Derajat kemasaman tanah $(\mathrm{pH})$ SAHE adalah 4.37 - 5.12. Lokasi ini memiliki suhu rata-rata tahunan berkisar antara $28-31{ }^{\circ} \mathrm{C}$. Berdasarkan kelas kesesuaian lahan untuk kelapa sawit, lokasi ini tergolong ke dalam kelas S2 (sesuai atau suitable) dengan faktor pembatas utama adalah tekstur tanah liat berdebu dan beberapa titik lahan yang rawan banjir. Berdasarkan klasifikasi kelas lahan, lokasi ini cukup sesuai untuk pengembangan 
kelapa sawit, namun harus diikuti dengan upaya untuk memperbaiki tingkat kesuburan tanah. Tanah tergolong ke dalam ordo entisol, hasil dari endapan sungai dan di klasifikasikan menjadi dua subgrup, yaitu: Humic Dystrudepts dan Typic Dystrudepts.

Jumlah rata-rata populasi/ha tanaman kelapa sawit di SAHE berkisar 129 tanaman/ha Produktivitas aktual kebun berdasarkan umur tanaman mulai tahun 2007-2011 rata-rata melebihi standar PPKS Marihat untuk kelas kesesuaian lahan S1, meskipun hasil survei tanah semi detil yang dilakukan badan riset First Resources menjelaskan bahwa kelas kesesuaian lahan SAH Estate termasuk kelas kesesuaian lahan S2. Perbandingan antara rata-rata produktivitas kelapa sawit SAH Estate berdasarkan tahun tanam dengan standar produksi PPKS Indonesia kelas S1 dan S2 disajikan pada Gambar 1.

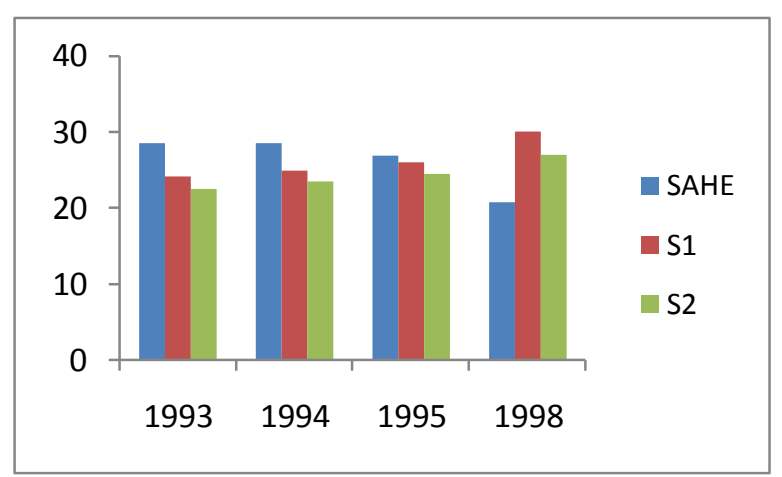

Gambar 1. Perbandingan produksi kelapa sawit SAHE dengan produksi PPKS pada kesesuaian lahan S1 dan S2

Fluktuasi produksi kelapa sawit diduga disebabkan oleh kondisi iklim yang berfluktuatif, salah satunya adalah penyebaran curah hujan yang tidak merata sepanjang tahun. Kondisi seperti ini tidak diharapkan oleh perusahaan karena mempersulit peramalan produksi sehingga proyeksi penerimaan dan rencana kegiatan operasional tidak sesuai dengan perkiraan yang dibuat sebelumnya. Oleh karena itu, pemahaman tentang pengaruh iklim terhadap produksi kelapa sawit, menjadi sangat penting untuk memprediksi produksi tandan buah segar kelapa sawit.

\section{Curah Hujan}

Menurut Siregar (2006) hujan merupakan sumber air utama di perkebunan kelapa sawit. Hujan juga berpengaruh terhadap pembungaan kelapa sawit. Berdasarkan pola hujan, lokasi magang termasuk kategori tipe Moonson yang bersifat unimodal. Hal ini dicirikan pola hujan memiliki satu puncak musim hujan, yaitu antara bulan Januari hingga Mei. Penurunan musim hujan di SAH Estate terjadi pada bulan Juni hingga Oktober dan mulai naik lagi pada bulan November. Bulan Maret 2008 dan bulan Desember 2011 terjadi peningkatan curah hujan yang cukup ekstrem dengan curah hujan mencapai $522 \mathrm{~mm}$ dan $631 \mathrm{~mm}$.

Curah hujan tahunan yang dimiliki oleh kebun berkisar antara 1,723 - 3,468 mm/tahun (Tabel 1). Defisit air dihitung dengan cara metode Tailiez (Siregar et al., 2006). Metode tersebut didasarkan pada perhitungan nilai keseimbangan air (neraca air). Nilai keseimbangan air diperoleh dengan menjumlahkan curah hujan $(\mathrm{mm})$ dengan cadangan awal air kemudian dikurangi evapotranspirasi. Asumsi yang digunakan adalah asumsi Evapotranspirasi bernilai $150 \mathrm{~mm} / \mathrm{bulan}$ jika hari hujan $\leq 10$ hari/bulan dan bernilai 120 $\mathrm{mm} /$ bulan jika hari hujan $>10$ hari/bulan. Kemampuan tanah dalam menyimpan air maksium $200 \mathrm{~mm}$. Defisit air terjadi apabila nilai keseimbangan air $<0 \quad \mathrm{~mm}$, sedangkan keseimbangan air dengan nilai $>0 \quad \mathrm{~mm}$ menunjukkan tidak terjadi defisit air. Apabila nilai keseimbangan air bernilai >200 mm, kelebihan air akan disimpan dalam tanah sebagai cadangan awal untuk bulan berikutnya dengan nilai maksimum $200 \mathrm{~mm}$.

Tabel 1. Defisit air pada tahun 2005-2011

\begin{tabular}{cccc}
\hline Tahun & $\begin{array}{c}\text { Hari hujan } \\
\text { (hari) }\end{array}$ & $\begin{array}{c}\text { Curah hujan } \\
(\mathrm{mm})\end{array}$ & $\begin{array}{c}\text { Water defisit } \\
(\mathrm{mm})\end{array}$ \\
\hline 2005 & 97 & 1723 & 80 \\
2006 & 92 & 1918 & 0 \\
2007 & 96 & 2148 & 0 \\
2008 & 115 & 3468 & 0 \\
2009 & 113 & 2585 & 0 \\
2010 & 111 & 1954 & 0 \\
2011 & 131 & 2618 & 0 \\
\hline
\end{tabular}

Penyinaran Matahari

Cahaya matahari sangat mempengaruhi pertumbuhan dan perkembangan kelapa sawit. Menurut Sastroutomo (1990) proses fotosintesis dikendalikan oleh cahaya, yaitu cahaya akan diubah menjadi energi kimia. Kemampuan penyerapan cahaya akan berbeda-beda untuk setiap jenis tumbuhan dan ini juga dipengaruhi oleh besarnya cahaya yang diterima. Grafik penyinaran matahari di lokasi magang pada tahun 2007-2010 dapat dilihat pada Gambar 2.

Berdasarkan Gambar 2 penyinaran matahari berkisar antara $30-70 \%$. Menurut Setyamidjaja (2006) lama penyinaran yang dibutuhkan oleh kelapa sawit adalah 5-7 jam/hari. 
Lama penyinaran mempengaruhi pertumbuhan, tingkat asimilasi, pembentukan bunga (sex ratio), dan produksi buah.

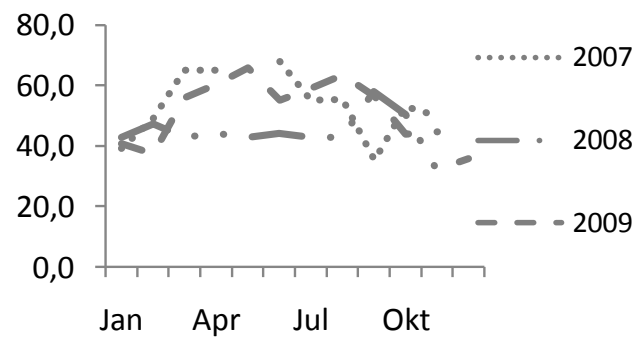

Gambar 2. Penyinaran matahari di SAHE

\section{Kecepatan Angin, Suhu, dan Kelembaban Udara}

Kecepatan angin rata-rata di lokasi magang pada tahun 2007-2010 berkisar antara 8$10 \mathrm{~km} / \mathrm{jam}$. Tanaman kelapa sawit dapat tumbuh baik pada kisaran suhu $24-28{ }^{\circ} \mathrm{C}$ dan kelembaban $85 \%$. Suhu rata-rata pada tahun 2005-2010 berkisar $27-29{ }^{\circ} \mathrm{C}$ dengan kelembaban rata-rata yaitu $74-81 \%$. Menurut Pahan (2010). Penyerbukan kelapa sawit secara anemophyli dan efektif pada kecepatan angin 5-6 km/jam. Angin terlalu kencang dapat menyebabkan tanaman baru menjadi miring, bahkan angin terlalu besar dapat merusak perkebunan kelapa sawit.

\section{Pemupukan}

Tanah di lokasi magang didominasi oleh tanah aluvial yang miskin unsur hara, terutama kation - kation basa seperti $\mathrm{Ca}, \mathrm{Fe}, \mathrm{Mg}, \mathrm{K}$ dan $\mathrm{Na}$. Hal ini menyebabkan tanaman memerlukan unsur hara tambahan atau pupuk agar pertumbuhan dan produktivitasnya terjaga dengan baik. Data historis pemupukan disajikan pada Tabel 2. Pemupukan kelapa sawit di kebun SAHE dalam lima tahun terakhir berjalan dengan baik dengan realisasi pemupukan rata-rata berkisar 93$100 \%$. Pemupukan kelapa sawit yang sesuai tepat cara, tepat jenis, tepat dosis, tepat tempat dan tepat waktu (5T) dapat memaksimalkan produksi kelapa sawit. Kurangnya dosis pupuk dapat berakibat terhambatnya pertumbuhan dan produksi tanaman (Poeloengan et al., 2007).

Tabel 2. Historis pemupukan kelapa sawit di lokasi magang tahun 2007-2011.

\begin{tabular}{cccc}
\hline Tahun & $\begin{array}{c}\text { Rekomendasi } \\
(\mathrm{kg})\end{array}$ & $\begin{array}{c}\text { Realisasi } \\
(\mathrm{kg})\end{array}$ & $\begin{array}{c}\text { Pencapaian } \\
(\%)\end{array}$ \\
\hline 2007 & 2123575 & 1962265 & 93 \\
2008 & 2212294 & 2155897 & 98 \\
2009 & 1635953 & 2015086 & 123 \\
2010 & 2216668 & 2158203 & 98 \\
2011 & 1987027 & 1991479 & 101 \\
\hline
\end{tabular}

\section{Analisis Faktor}

Analisis faktor dilakukan untuk mengetahui faktor-faktor yang mempengaruhi hasil produksi kelapa sawit. Pada Analisis Faktor kali ini menggunakan metode yang dikembangkan oleh Sulistyo (2010) yaitu dengan menguji pengaruh setiap peubah terhadap hasil produksi menggunakan uji t-parsial. Peubah yang diuji meliputi curah hujan, hari hujan, suhu, kelembaban udara, kecepatan angin, penyinaran matahari, pemupukan, umur tanaman, dan defisit air. Hasil uji t-parsial untuk peubah yang diduga berpengaruh terhadap produksi kelapa sawit disajikan dalam Tabel 3.

Tabel 3. Hasil uji t-parsial

\begin{tabular}{lllllc}
\hline \multicolumn{1}{c}{ Peubah } & \multicolumn{5}{c}{ P-value } \\
\cline { 2 - 5 } & 0 BSP & 6 BSP & 12 BSP & 18 BSP & 24 BSP \\
\hline Umur tanaman & $0.022^{*}$ & - & - & - & - \\
Populasi & 0.121 & - & - & - & $0.007^{* *}$ \\
Pupuk & $0.043^{*}$ & 0.493 & $0.055^{*}$ & 0.217 & 0.586 \\
Suhu udara & 0.893 & 0.616 & 0.587 & 0.589 & 0.853 \\
Kelembaban udara & 0.348 & $0.045^{*}$ & 0.626 & 0.130 & 0.604 \\
Kecepatan angin & 0.971 & 0.604 & 0.317 & $0.007^{* *}$ & 0.791 \\
Penyinaran matahari & 0.132 & 0.957 & 0.067 & $0.049^{*}$ & 0.130 \\
Hari hujan & 0.879 & 0.441 & 0.862 & 0.974 & 0.216 \\
Curah hujan & 0.385 & $0.047^{*}$ & 0.053 & 0.281 & 0.092 \\
Defisit air & $0.021^{*}$ & 0.793 & 0.752 & $0.007^{* *}$ \\
\hline
\end{tabular}

Keterangan : ${ }^{*}$ Berbeda nyata pada $\left.\alpha=1 \%, * *\right)$ Berbeda nyata pada $\alpha=5 \%$, BSP : Bulan Sebelum Panen

Data panen yang diperoleh oleh penulis lengkap dari tahun 2007-2011, tetapi data yang lain seperti data suhu udara, kelembaban udara, kecepatan angin, dan penyinaran matahari hanya tersedia hingga 2010. Oleh karena itu, dasar perhitungan untuk analisis menggunakan data hingga 2010. Hasil analisis produksi duga dan akurasi peramalan disajikan pada Tabel 4 .

Berdasarkan hasil dari keenam persamaan regresi linear berganda pada Tabel 4, didapatkan 
produksi duga dan akurasi peramalan (selisih) yang mendekati produksi aktual kebun. Produksi duga hasil persamaan regresi memiliki selisih atau kesalahan yang lebih kecil dibandingkan dengan budget produksi yang dibuat oleh kebun. Seluruh hasil produksi duga dari keenam persamaan regresi pada tahun 2010 mendekati produksi aktual dibandingkan budget produksi kebun dengan kisaran selisih $0.21-9.30 \%$. Hal ini memperlihatkan bahwa keenam model persamaan regresi tersebut dapat digunakan dalam peramalan.

Tabel 4. Hasil produksi duga dan akurasi peramalan menggunakan regresi linear berganda pada produksi kelapa sawit tahun 2010

\begin{tabular}{|c|c|c|c|c|c|}
\hline \multirow{2}{*}{ Persamaan } & Produksi aktual & Produksi duga & Selisih (1) & Budget produksi & Selisih (2) \\
\hline & (a) & (b) & $(\%)$ & (c) & $(\%)$ \\
\hline \multicolumn{6}{|l|}{ Tahun 2010} \\
\hline RLB I & 25.38 & 24.52 & 3.37 & 29.50 & 16.24 \\
\hline RLB II & 25.38 & 23.52 & 7.34 & 29.50 & 16.24 \\
\hline RLB III & 25.38 & 25.33 & 0.21 & 29.50 & 16.24 \\
\hline RLB IV & 25.38 & 24.03 & 5.30 & 29.50 & 16.24 \\
\hline RLB V & 25.38 & 27.08 & 6.71 & 29.50 & 16.24 \\
\hline RLB VI & 25.38 & 27.74 & 9.30 & 29.50 & 16.24 \\
\hline \multicolumn{6}{|l|}{ Tahun 2009} \\
\hline RLB I & 27.37 & 24.02 & 12.20 & 29.47 & 7.71 \\
\hline RLB II & 27.37 & 23.21 & 15.17 & 29.47 & 7.71 \\
\hline RLB III & 27.37 & 24.28 & 11.26 & 29.47 & 7.71 \\
\hline RLB IV & 27.37 & 23.36 & 14.61 & 29.47 & 7.71 \\
\hline RLB V & 27.37 & 25.47 & 6.91 & 29.47 & 7.71 \\
\hline RLB VI & 27.37 & 26.50 & 3.13 & 29.47 & 7.71 \\
\hline
\end{tabular}

Berdasarkan keenam model persamaan regresi linear berganda (RLB) terdapat model persamaan regresi yang paling mendekati produksi aktual kebun yaitu model persamaan RLB III. Pada model persamaan RLB III memiliki selisih atau tingkat kesalahan $0.21 \%$ pada produksi tahun 2010 walaupun pada tahun 2009 tingkat kesalahan mencapai $11.26 \%$. Model persamaan RLB III yaitu :
Produksi $=0.0127$ umur tanaman $(0 \mathrm{BSP})-0.0187$ pupuk $(18 \mathrm{BSP})+0.0404$ kelembaban udara $(6 \mathrm{BSP})-$ 0.0126 penyinaran matahari (18 BSP) -0.000922 curah hujan (6 BSP) -0.00371 defisit air $(0$ BSP) -0.0205 hari hujan (18 BSP) -0.32

Model persamaan regresi linear berganda (RLB) III dapat digunakan untuk meramal produksi tahunan kelapa sawit di lokasi magang dengan menjumlahkan produksi bulanan pada tahun tersebut. Kekurangan persamaan regresi linear berganda III ini adalah tidak dapat digunakan untuk meramal produksi bulanan karena nilai produksi duga bulanan yang dihasilkan belum akurat. Selain itu, data iklim yang digunakan masih menggunakan data iklim daerah Pekanbaru yaitu stasiun terdekat dengan wilayah kebun. Penggunaan persamaan regresi linear berganda III belum akurat untuk meramal produksi tanaman kelapa sawit yang rata-rata berumur 15 tahun karena produksi kelapa sawit cenderung menurun mulai umur 14-25 tahun.

Bentuk persamaan regresi linear berganda III mempunyai potensi untuk meramal produksi pada wilayah perkebunan di Kabupaten Rokan Hulu dengan kultur teknis yang optimal dan jenis tanah atau kondisi kelas kesesuaian lahan yang mirip dengan kebun. Potensi penggunaan model peramalan untuk wilayah lebih luas dapat dilakukan apabila wilayah tersebut mempunyai kondisi iklim yang hampir sama.

\section{KESIMPULAN}

Faktor iklim dan kultur teknis memegang peranan penting dalam peramalan produksi kelapa sawit. Analisis faktor produksi yang diuji meliputi curah hujan, hari hujan, suhu, kelembaban udara, kecepatan angin, penyinaran matahari, pemupukan, umur tanaman, dan defisit air. Peubah-peubah yang berpengaruh nyata yaitu umur tanaman, pemupukan pada 0 BSP dan 18 BSP, kelembaban udara pada 6 BSP, penyinaran matahari pada 18 BSP, curah hujan pada 6 BSP, hari hujan pada $18 \mathrm{BSP}$, dan defisit air pada 0 BSP dan 24 BSP.

Bentuk persamaan regresi linear berganda III mempunyai potensi untuk meramal produksi 
tahunan dengan selisih atau tingkat kesalahan $0.21-11.26 \%$ pada wilayah perkebunan di Kabupaten Rokan Hulu dengan kultur teknis yang optimal dan jenis tanah atau kondisi kelas kesesuaian lahan yang mirip dengan lokasi magang.

\section{DAFTAR PUSTAKA}

Aritonang, R. 2009. Peramalan Bisnis. Jakarta (ID): Ghalia Indonesia.

Pahan, I. 2010. Panduan Lengkap Kelapa Sawit. Edisi IV. Jakarta (ID): Penebar Swadaya.

Poeloengan, Z., Fadli, M. I., Winarna, Rahutomo, S., Sutarta, E.S. 2007. Permasalahan pemupukan pada perkebunan kelapa sawit. Dalam Darmosakoro, W., Sutarta, E.S., Winarna $(E d s)$. Lahan dan Pemupukan Kelapa Sawit. Medan (ID): Pusat Penelitian Kelapa Sawit.

Sastrosayono, S. 2003. Budidaya Kelapa Sawit. Jakarta (ID): Agromedia Pustaka.
Sastroutomo, S.S. 1990. Ekologi Gulma. Jakarta (ID): PT. Gramedia Pustaka Utama.

Setyamidjaja, D. 2006. Kelapa Sawit (Tehnik Budidaya, Panen, dan pengolahan). Yogyakarta(ID): Kanisius.

Siregar, H.H., Darian, N.H., Hidayat, T.C., Darmosakoro, W., Harahap, I.Y. 2006. Hujan Sebagai faktor Penting untuk Perkebunan Kelapa Sawit. Medan (ID): Pusat Penelitian Kelapa Sawit.

Sulistyo, H. 2010. Identifikasi Parameter Agronomi untuk Pengembangan Taksasi Produksi Kelapa Sawit (Elaeis guineensis Jacq.) di Angsana Estate, Minamas Plantation, Tanah Bumbu, Kalimantan Selatan.

Sunarko. 2009. Budidaya dan Pengelolaan Kebun Kelapa Sawit dengan Sistem Kemitraan. Jakarta (ID): Agromedia Pustaka. 